\title{
Klodens klimakterium
}

\section{Frede Vestergaard}

\section{Klimapolitikkens historie. EU spiller en afgørende rolle i kampen for at reducere udslippet af driv- husgasser i verden. Men opgaven er gigantisk: Faktisk bliver det en kæmpe udfordring bare at sørge for, at udslippet ikke øges}

De sidste par år har vi været vidne til en intens diskussion om bekæmpelse af klimaændringer og global opvarmning. Det er en naturvidenskabelig kendsgerning, at kuldioxid, $\mathrm{CO}_{2}$, metan og visse andre gasser virker som drivhusgasser, der forstærker den naturlige drivhuseffekt.

Det er også en kendsgerning, at atmosfærens indhold af drivhusgasser er steget efter den industrielle revolution, der var baseret på den nye energikilde kul, der senere blev suppleret med olie og gas. Atmosfærens stigende koncentration af drivhusgasser antages derfor sammen med naturlige klimatiske variationer i et eller andet omfang at være medvirkende til de senere års klimatiske ekstremer i mange lande.

I en række lande, især de nordeuropæiske, har klima- og energipolitikken længe været i højsædet. Hvor kampen om skatter og økonomisk fordeling mellem de forskellige samfundsgrupper tidligere stod højest på den politiske dagsorden, er klima- og energiproblematikken blevet vigtige politikområder for partier på såvel venstre- som højrefløjen. Partier kappes om at love reduktion af udslippet af drivhusgasser og om at omlægge energiforsyningen fra fossilt brændsel til vedvarende energi.

Takket være EU-samarbejdet er klimaet blevet ophøjet til også at være en central faktor i international politik. Uden EU som pådriver ville FN's klimakonvention uden tvivl have ført en meget tilbagetrukket tilværelse.

Kyoto-aftalen fra 1997 om reduktion af udslippet af klimagasser, først og fremmest kuldioxid $\mathrm{CO}_{2}$, ville aldrig været blevet til noget, og i hvert fald ville den være afgået ved døden, hvis ikke EU havde insisteret på at holde den i live, efter at præsident 
Bush i 2001 afviste at søge senatets ratifikation af aftalen med den begrundelse, at den ikke omfatter udviklingslandene.

Det betyder dog ikke, at amerikanerne er ligeglade med klimaet.

I de seneste par år er hypotesen om menneskets påvirkning af klimaet også kommet på den offentlige dagsorden i USA, blandt andet som konsekvens af orkanen Katharina, der i 2005 resulterede i en oversvømmelse af store dele af New Orleans, og Al Gores film An inconvenient Truth.

I USA og Canada er klimaet blevet blandt de vigtigste forhold, der bekymrer folk i holdningsundersøgelser.

Den konservative canadiske premierminister Stephen Harper blev i begyndelsen af indeværende år tvunget til at udskifte sin miljøminister, der havde betvivlet den menneskeskabte klimaeffekt såvel som Kyoto-processen.

Og flere amerikanske delstater først og fremmest Californien - har vedtaget forskellige tiltag til begrænsning af udslippet af drivhusgasser. I kongressen er det demokratiske flertal også begyndt at røre på sig med forskellige forslag til blandt andet fremme af vedvarende energi.

Den republikanske administration har dog fastholdt sin modstand mod Kyoto-protokollen, men præsident Bush har lanceret forskellige ikke-bindende mål, blandt andet for forbedring af energiintensiteten - altså ener- giforbruget pr. produceret enhed.

I 2002 opstillede præsident Bush således et mål for en forbedring af energiintensiteten på 18 procent frem til 2012, men et fald i energiforbruget pr. produceret enhed som er en udvikling, der har været i gang i USA og mange andre lande er ikke det samme som et fald i selve energiforbruget eller i udledningen af drivhusgasser. Han har også igangsat og støttet et ethanol program, der har resulteret i en stærk vækst i dyrkningen af majs.

I EU håber mange på, at en mulig demokratisk administration fra 2009 vil være indstillet på at indgå i forhandlinger om bindende forpligtelser i afløseren for Kyoto-aftalen, der udløber i 2012.

Den manglende amerikanske ratifikation af Kyoto-protokollen har medvirket til at øge den almindelige skepsis over for USA i disse år i brede dele af den europæiske offentlighed.

\section{Kyotos efterfølger}

Klimapolitikkens efterhånden centrale placering i international politik har haft til følge, at den ikke længere en sag alene for miljø- og energiministre. I de sidste par år er statsog regeringscheferne blevet stærkt involveret.

Klimaet havde således topprioritet på G-8-møderne i Gleneagles i 2005 og i Heiligendamm i 2007 og delvis også i Skt. Petersborg i 2006, hvor 
energiforsyningen dog havde forrang.

I FN afholdt Sikkerhedsrådet i foråret et særligt møde om truslen fra klimaændringer på britisk initiativ, og den 31. juli-2. august havde FN's generalforsamling sit første - ganske vist uformelle - møde om klimapolitikken.

Og den 24. september - dagen før FN's generalforsamling åbnede havde generalsekretær Ban Ki-moon indkaldt til en klimakonference i New York med stats- og regeringsledere fra omkring 100 lande. Generalsekretæren vil med mødet forsøge at bryde de fastlåste positioner forud for FN's 13. klimakonference, der finder sted på Bali i december.

På mødet på Bali skal forhandlingerne om en afløser for Kyoto-protokollen senest begynde, hvis forhandlerne skal kunne nå at lave en post-Kyoto-aftale på FN's 15. klimakonference, der skal finde sted i København i december 2009. Faktisk skaber den manglende afklaring af, om Kyoto-protokollens regelværk gælder efter 2012, allerede usikkerhed om den økonomiske værdi af investeringer i energibesparelser uden for EU - og dermed for den såkaldte kvotehandel.

Forinden afholdes imidlertid det årlige møde i Asia-Pacific Economic Cooperation, og ifølge udkastet til deklaration fra mødet, vil APEC-landene, der ud over bl.a. Kina, Indonesien og Filippinerne omfatter USA, Canada, Australien og Rus- land, arbejde for at forbedre energieffektiviteten med 25 procent frem til 2030 og for at øge skovarealerne med 20 millioner hektar frem til 2020. Men nogen udslipsbegrænsning er der ikke tale om.

\section{Bush-administrationens argumenter}

I dagene efter FN-konferencen i New York har præsident Bush arrangeret et klimamøde i Washington den 27. og 28. september under udenrigsminister Condoleezza Rices ledelse for stats- og regeringscheferne fra de 15 lande, der har den største udledning af drivhusgasser, samt lederne af Europa-kommissionen og EU-formandslandet Portugal.

I invitationen til de 15 lande, der repræsenterer 85 af det globale $\mathrm{CO}_{2}$-udslip, skrev præsident Bush blandt andet.: "På dette møde vil vi søge at opnå enighed om den proces, hvorunder de store økonomier ved udgangen af 2008 kunne enes om en post-2012 struktur, der kunne omfatte et langsigtet globalt mål, nationalt definerede mellemlange mål og strategier, og sektorbaserede fremgangsmåder for forbedring af energisikkerheden og for reduktion af drivhusgasemissioner."

Præsident Bush bebudede allerede før G-8 mødet i Heiligendamm i juni, at han ville invitere til et sådan møde, og han blev dengang kritiseret for at ville kortslutte FN-processen. På G-8-mødet gav han dog til- 
sagn om, at USA vil indgå i forhandlingerne i FN-regi om en afløser for Kyoto-aftalen, men invitationen til mødet i Washington tyder på, at den amerikanske regering ikke helt har opgivet tanken om et parallelt forhandlingsforløb uden for rammerne af Kyoto-protokollen.

Fra amerikansk side lægges der stor vægt på, at de halvindustrialiserede, store udviklingslande Kina, Indien, Brasilien, Mexico, og Sydafrika bliver omfattet af en vis $\mathrm{CO}_{2}$ - begrænsning, hvis USA skal gå med i en eller anden form for aftale.

Argumentet er, at der ellers er risiko for, at virksomheder i USA og andre lande flytter energikrævende produktion til udviklingslandene, således at $\mathrm{CO}_{2}$-udslippet kun bytter land. Det, man fra amerikansk side som minimum ønsker, er, at der kommer til at gælde de samme regler for udslip fra for eksempel stålindustrien, uanset om produktionen foregår i et industrialiseret land eller i et udviklingsland. Altså, at der til en begyndelse gennemføres sektorbestemte regler, som er ens i alle lande, så udslipbegrænsninger i de industrialiserede lande ikke udhules ved flytning af produktion til udviklingslande.

\section{Kinas argumenter}

Kina og Indiens holdning er imidlertid, at så længe USA ikke underkaster sig begrænsninger, vil de heller ikke gøre det.
Kina gør gældende, at selv om Kina snart bliver verdens største udleder af drivhusgasser - ifølge en hollandsk beregning er det allerede i år - var udledningen på 3,65 tons pr. indbygger i 2004 stadig kun en tredjedel af den gennemsnitlige udledning i OECD-landene og en femtedel af det amerikanske niveau.

Ma Kai, der er minister med ansvar for Kinas planlægningskommission, sagde før G-8-mødet i juni, at "vores generelle holdning er, at Kina ikke skal forpligte sig til nogen form for kvantitative reduktionsmål for udslip af drivhusgasser, fordi Kina stadig er et land i udvikling." Dog ville han ikke afvise mål for den såkaldte energiintensitet.

Kinas nationale mål er, at energiintensiteten skal være forbedret med 20 procent i 2010. Forbedret energieffektivitet betyder imidlertid kun et lavere udslip pr. produceret enhed. Det samlede udslip stiger i takt med den økonomiske vækst.

Minister Ma Kai gjorde ved samme lejlighed gældende, at den kinesiske et-barns politik allerede har bidraget til en kraftig reduktion af det kinesiske udslip. Den vigtigste faktor bag væksten i kuldioxidudslip er befolkningsudviklingen, erklærede han. Kineserne gør gældende, at uden et-barns politikken ville Kina i år have haft 1,6 milliarder mennesker i stedet for 1,3 milliarder.

Om den stærke vækst i Kinas udslip i de senere år, sagde Ma Kai, at den delvis afspejlede Kinas store eks- 
port af energiintensive varer, der forbruges andre steder i verden. Derfor er forbrugerne i andre lande på en måde ansvarlige for udslippet, mente han.

Han nævnte som eksempel, at Kina sidste år eksporterede 24 millioner tons stål.

Minister Ma Kai fortsatte med at sige, at når Vesten stiller krav til Kina og andre udviklingslande om at begrænse deres $\mathrm{CO}_{2}$-udslip, er det hverken realistisk eller fair, for de udviklede lande er ansvarlige for størstedelen af de menneskeskabte drivhusgasser, der befinder sig i atmosfæren. Fra starten af den industrielle revolution frem til 1950 stod de udviklede lande for 95 procent af udledningen af kuldioxid. Fra 19502002 var det 77 procent, og disse udslip har bidraget til de rige landes udvikling. Man kan altså ikke kun se på udledningens omfang, men må også se på hvilket udviklingsniveau et land har nået, når man skal vurdere dets udslip, lød det fra den kinesiske minister.

Han anerkendte dog, at det er nødvendigt at begrænse udledningen af drivhusgasser. Men det må ske efter princippet om "fælles, men differentieret ansvar", som betyder, at det er de udviklede lande, der skal gå i spidsen med nedskæringer.

Ma Kai betvivlede i øvrigt den videnskabelige baggrund for EU's klimamålsætning, der lyder på en stigning på maksimalt to graders celsius i den globale middeltemperatur, for at begrænse de værste konsekvenser af klimaændringerne.

"Jeg er bange for, at denne grænse stadig mangler videnskabelig evidens såvel som tilknyttet forskning", sagde han.

Ma Kais udtalelser faldt i forbindelse med præsentationen af Kinas første klimaplan nogensinde. Det fremgår af den kinesiske plan, at biomasse, vind- og solenergi skal stå for 10 procent af energiforsyningen i 2010 og 16 procent i $2020 \bmod$ syv procent i dag. Ifølge tidligere annoncerede planer vil Kina bruge 50 milliarder dollars på at bygge 32 kernekraftværker inden 2020. I dag tegner fossile brændsler, fortrinsvis kul, sig for cirka 90 procent af Kinas samlede energiforsyning.

\section{Rapporternes anbefalinger}

De mange møder og initiativer i EU og på G-8 plan er i løbet af det sidste års tid blevet understøttet af en række rapporter om den fremtidige udvikling i klimaet.

Det gælder først og fremmest den fjerde hovedrapport fra FN's mellemstatslige klimapanel IPCC og den britiske Stern-rapport om omkostningerne ved at undlade indgreb over for udslippet af klimagasser. Stern-rapporten anbefaler, at verden årligt bruger 1 procent af det globale bruttonationalprodukt på at bekæmpe klimaændringer svarende til 2000 milliarder kroner eller godt og vel Danmarks samlede 
bruttonationalprodukt. Ellers må verden være indstillet på at tåle årlige skader, som er 15-20 gange højere.

Den internationale klimapolitik er som sagt blevet holdt i live af EU. I de sidste par år har klima og energi været blandt de allervigtigste emner på EU-landenes topmøder. EU har hidtil kun haft begrænsede fælles regler på energiområdet, men i løbet af det sidste år er det kommet højt på dagsordenen. I januar i år fremlagde Europa-Kommissionen en omfattende energipakke med forslag til at realisere EU's klimapolitik. På energiområdet har Ruslands midlertidige afbrydelse af naturgasforsyningen til Ukraine i begyndelsen af 2005 og de høje oliepriser virket som en yderligere katalysator for forsøget på at etablere en fælles energipolitik.

På EU-topmødet den 8.-9. marts i år lykkedes det forbundskansler Angela Merkel - der selv var miljøminister under kansler Helmut Kohl fra 1994-98 - at samle EU's medlemsstater om en fælles klima- og energipolitik sammenfattet i formlen 202020. Det vil sige 20 procent mindre udslip af drivhusgasser, 20 procent større energieffektivitet og 20 procent af energiforsyningen baseret på vedvarende energi som sol, vind og vandkraft. Alt sammen inden 2020. Hvordan disse mål skal fordeles blandt de enkelte lande står tilbage at beslutte, men Europa-Kommissionen satser på, at det sker på et ministerrådsmøde i EU den 3. december, dvs. samme dag som FN's klimakonference på Bali begynder. Slagsmålet om at undgå sorteper er allerede begyndt. Et lækket dokument fra det britiske erhvervsministerium til de øvrige ministre har gjort gældende, at det vil koste ca. 1000 pund pr. husstand i meromkostninger til elektricitet, hvis 20 procent af den britiske energiforsyning skal komme fra vedvarende energi.

EU-udslippet af drivhusgasser skal fortsat reduceres også efter 2020, for stats- og regeringscheferne vedtog yderligere, at udslippet af drivhusgasser skal halveres inden 2050 målt i forhold til 1990. Det skal også være EU's mål i de globale klimaforhandlinger.

Dermed skulle stigningen i den globale middeltemperatur kunne begrænses til 2 graders celsius, lyder det fra Europa-Kommissionen.

I EU's energi- og klimaplaner indgår, at EU som forsøg skal bygge 12 kraftværker, hvor $\mathrm{CO}_{2}$-udslippet deponeres i undergrunden. Det indgår også, at 10 procent af brændstoffet til transport i 2020 skal komme fra biomasse, noget der vil øge det dyrkningsmæssige pres på naturen.

I USA er der allerede som følge af præsident Bush's initiativer på energiområdet ved at opstå en ikke ubetydelig produktion af biobrændstof baseret på majs, om end den er beskeden målt i forhold til det samlede amerikanske forbrug af brændstof til transport. En bivirkning har været, at priserne på majs og andre 
kornprodukter globalt er på det højeste niveau i en årrække.

EU-lederne vedtog altså på topmødet i marts at arbejde for, at afløseren for Kyoto-aftalen sætter som mål at reducere udslippet af drivhusgasser med mindst 20 procent $-i$ forhold til 1990 - frem til $2020 \mathrm{og}$ 50 procent frem til 2050.

Til sammenligning påtog de udviklede lande sig i Kyoto at reducere deres udslip af drivhusgasser med 68 procent fra 1990 frem til 2012.

\section{Principperne fra Kyoto}

Ud fra et princip om "fælles, men differentieret ansvar", blev ulandene derimod fritaget for reduktionsforpligtelser.

Dels har de allerfleste af dem et langt lavere $\mathrm{CO}_{2}$-udslip pr. indbygger end industrilandene, og dels gjorde de gældende, at det er de industrialiserede lande, der bærer hovedansvaret for den hidtidige stigning i atmosfærens koncentration af drivhusgasser. Derfor må de industrialiserede lande også tage de første skridt til at mindske udledningen af drivhusgasser.

De daværende 15 EU-lande påtog sig at reducere deres udslip med 8 procent. USA - med vicepræsident Al Gore som delegationsleder - påtog sig en reduktion på 7 procent, mens Japan forpligtede sig til en reduktion på 6 procent.

Alt i alt blev aftalen lanceret som en samlet reduktion på 5,2 procent i industrilandenes udslip af drivhusgasser fra 1990 til 2008-12.

Det er dog vigtigt for forståelsen af aftalen at understrege, at Kyotoprotokollen ikke kræver, at reduktionen sker internt i det enkelt lande. Et land kan også opfylde sin reduktionsforpligtelse ved at købe ubrugte udslipskvoter $i$ andre lande eller ved at investere i $\mathrm{CO}_{2}$-besparelser i udviklingslande.

EU-landene aftalte efter mødet $\mathrm{i}$ Kyoto en indbyrdes fordeling af byrden ved at opnå den lovede reduktion på 8 procent, således at nogle lande påtog sig at reducere mere end 8 procent og andre lande mindre.

Den danske regering påtog sig $\mathrm{i}$ denne interne EU-aftale at reducere med 21 procent fra 1990 til 2012, i øvrigt ligesom Tyskland.

Reelt er der dog for Danmarks vedkommende tale om 28 procent målt i forhold til det korrigerede normaludslip for 1990. Til gengæld fik lande, som Spanien, Portugal og Irland mulighed for at øge deres forholdsvis lave udslip.

At Danmark reducerer sit udslip med 28 procent frem for de i Kyoto aftalte 8 procent bringer altså ikke verden nærmere en samlet reduktion af drivhusgasudslippet. Det er alene udtryk for en solidarisk handling - hvis en sådan eksisterer mellem stater.

De danske miljøministre Svend Auken og nu Connie Hedegaard har i øvrigt i årenes løb placeret sig 
som centrale spillere i de internationale klimaforhandlinger, både i og uden for EU-systemet.

Connie Hedegaard tog for et par år siden initiativ til at invitere en række betydende miljøministre fra bl.a. de store udviklingslande til Grønland for at studere klimaændringer i Illullisat. Det er efterfølgende resulteret i et uformelt årligt møde i denne kreds, i Sydafrika i 2006 og i Nordsverige i 2007.

Senere er Grønlandsmødet fulgt op med invitationer til centralt placerede amerikanske senatorer, heriblandt præsidentkandidaterne Hillary Clintion og John McCain, og senest forbundskansler Angela Merkel.

Om Svend Auken fortælles den sande - anekdote, at den tidligere franske miljøminister Michel Barnier under et ministermøde i EU sagde til Auken: "Vi har vænnet os til, at du taler, som om du repræsenterer 50 millioner danskere, men det er svært at vænne sig til, at I er 500 millioner". Trods den lette ironi var bemærkningen ment anerkendende.

I USA gjorde præsident Bill Clinton ikke noget forsøg på at få det amerikanske senat til at ratificere Kyoto-protokollen, formentlig fordi senatet inden Kyoto-konferencen med 95 stemmer mod nul havde udtalt, at uden at de store udviklingslande blev omfattet af en form for $\mathrm{CO}_{2}$-begrænsning, kunne der ikke blive tale om at godkende en even- tuel aftale fra Kyoto. Få måneder efter sin tiltræden - i marts 2001 - afviste præsident George W. Bush Kyoto-aftalen, som han kaldte mangelfuld og ineffektiv fordi den ikke omfattede 80 procent af verden, og fordi den ville skade USA's økonomi.

Den manglende amerikanske ratifikation bevirkede, at protokollens ikrafttræeden kom til at afhænge af, om Rusland ville ratificere aftalen, hvilket russerne benyttede sig af til at afpresse EU forskellige indrømmelser for at underskrive aftalen, blandt andet i forbindelse med Ruslands ansøgning om medlemskab af WTO. Russerne ratificerede traktaten i november 2004 og tre måneder senere kunne Kyoto-protokollen langt om længe træde i kraft i februar 2005 .

\section{Klimapolitikkens fødsel}

Klimapolitikkens oprindelse dateres ofte til Kyoto-aftalen fra 1997. Men i virkeligheden blev klimaet sat på den internationale politisk-videnskabelige dagsorden allerede i 1980'erne. Specielt fik et par konferencer i Villach i Østrig i 1985 og i Toronto i 1988 betydning ved bl.a. at lægge grundstenen for FN's klimapanel, IPCC. Det blev etableret i november 1988 af World Meteorological Organisation og FN's miljøorganisation UNEP, som er to af de tre organisationer, som havde arrangeret Villachkonferencen. Den tredje var den Internationale videnskabelige Union 
ICSU. IPCC består af nogle hundrede videnskabsmænd, som med 5-6 års mellemrum udvælger og sammenfatter den eksisterende viden om klimaets udvikling på forskellige områder og diskuterer den med andre forskere. Inden offentliggørelsen bliver rapporterne gennemtygget sætning for sætning af embedsmænd fra miljøministerierne. Dette arbejde foregår ved konsensus-beslutning. Proceduren har som konsekvens, at videnskabelige kritikere af IPCC's vurderinger efterfølgende kommer til at fremstå som afvigere.

Den fjerde hovedrapport siden etableringen i 1988 blev offentliggjort i februar i år. Eller rettere: Den politiske sammenfatning - Summary for Policymakers - på 23 sider. Selve den naturvidenskabelige rapport på mere end 1000 sider blev først offentliggjort i maj for - med IPCC's egne ord - at sikre 'konsistens' mellem den politiske sammenfatning og selve den videnskabelige rapport.

I den politiske sammenfatning vurderes det, at "det er meget sandsynligt, at den observerede stigning i koncentrationen af drivhusgasser har forårsaget det meste af de gennemsnitlige temperaturstigninger, der er sket siden midten af det 20. århundrede."

Dermed var tonen skærpet i forhold til den forrige rapport fra 2001, som talte om, at "det er sandsynligt, at det meste af den observerede opvarmning gennem de sidste 50 år skyldes stigningen i koncentra- tionen af drivhusgasser" i atmosfæren.

\section{Skræmmende læsning}

Sammenfatningen er skræmmende læsning.

IPCC arbejder med fremskrivninger af såkaldte scenarier baseret på computermodeller. Og de nye modelberegninger viser, at fremtidige klimaændringer vil blive langt mere ødelæggende og vise sig hurtigere end tidligere antaget.

Hyppigheden af ødelæggende orkaner og storme vil stige dramatisk. Havene vil stige omkring en halv meter i løbet af de næste hundrede år. Det arktiske ocean vil blive isfrit om sommeren. Den permanente snedækning vil forsvinde fra alle bjerge bortset fra de højeste. Ørknerne vil brede sig. Surhedsgraden i oceanerne vil stige, hvilket vil dræbe koralrev og atoller, og dræbende hedebølger vil blive mere hyppige.

Afhængigt af det valgte scenarie lyder IPCC's fremskrivninger på en stigning i den globale gennemsnitstemperatur på 1,8-4,0 grader (i såkaldt best estimate) frem til år 2100 .

Forventningerne til det fremtidige klima bygger i høj grad på økonomiske vækstmodeller og ikke kun naturvidenskabelige sammenhænge. Det skyldes, at den menneskeskabte udledning af drivhusgasser opstår som følge af økonomisk aktivitet. Det er derfor den økonomiske aktivitet igennem de næste 100 år, der 
vil være afgørende for, hvor meget drivhusgas, der bliver udledt og påvirker klimaet. IPCC's fremskrivninger hundrede år frem afhænger altså af kvaliteten af de nationaløkonomiske modeller.

2001-rapportens fremskrivninger blev skarpt kritiseret af en række velestimerede $\varnothing$ konomer og statistikere såsom OECD's tidligere cheføkonom David Henderson og den tidligere australske rigsstatistiker Ian Castles. De pegede på, at manglende korrektion for købekraft bevirker, at IPCC's modeller overdriver den fremtidige $ø$ konomiske vækst i udviklingslandene - og dermed også overdriver de næste hundrede års udledning af drivhusgasser og deraf følgende klimaændringer.

IPPC valgte ikke desto mindre at lave den fjerde hovedrapport på grundlag af de gamle økonomiske scenarier, men har stillet i udsigt, at de vil blive vurderet før en ny hovedrapport.

\section{Brundtland-kommissionen}

At klimapolitikken kom på den politiske dagsorden i 1990'erne hænger også sammen med FN's store konference om Miljø og Udvikling i Rio de Janeiro i 1992.

Forud for denne konference var jordbunden gødet af begrebet bæredygtig udvikling, som i 1987 blev lanceret af FN's Verdenskommission for Miljø og Udvikling, også kaldet Brundtland-kommissionen i rappor- ten Vor falles Fremtid. I modsætning til anbefalingerne i FN-rapporten North-South: A Programme of Survival fra 1983 fra Den Uafhængige Kommission for Internationale Udviklingsspørgsmål, også kaldet Willy Brandt-kommissionen, lykkedes det Brundtland-kommissionen at vinde mediernes og offentlighedens - og dermed politikernes - opmærksomhed om de globale miljøproblemer og specielt klimaproblematikken i store dele af den rige, vestlige verden.

Brundtland-kommissionen definerede bæredygtighed som en holdning til fremskridt, der opfylder de nuværende behov uden at sætte fremtidige generationers mulighed for at opfylde deres behov over styr.

Begrebet bæredygtighed blev i de følgende år lidt af et slogan for miljødebatten i mange lande, og det kom til at præge Rio-konferencen i 1992. Selv om Rio-konferencen handlede om både miljø og udvikling, vedrørte konferencens beslutninger først og fremmest miljøsiden.

Konferencen mundede ud i flere forskellige miljøkonventioner. En af dem var klima-konventionen, som hurtigt blev underskrevet af alle verdens lande. I de følgende år var den rammen om en række møder med henblik på lave en aftale om en reduktion af udslippet af drivhusgasser. Kyoto-protokollen blev aftalt ved det tredje af disse møder i december 1997.

Den overordnede ide i Kyoto-pro- 
tokollen er at gøre kulstof dyrere og dermed fremme energiformer, der ikke er baseret på kul, olie eller naturgas. Det kunne man - for så vidt meget mere enkelt - gøre ved at indføre en global skat på fossilt brændsel, men det blev anset for at være endnu sværere at gennemføre politisk - i ikke mindst USA - end Kyoto-aftalens cap-and-trade-system, hvor det i princippet er markedet, der får prisen ved at bruge fossilt brændsel til at stige.

Sammenlignet med et tredje alternativ, et kommandosystem, der dekreterer, hvor meget $\mathrm{CO}_{2}$ en virksomhed må udlede, har kvotehandlen den fordel, at nedskæringen kommer til ske, hvor det er billigst for samfundet.

\section{Handel med kvoter}

EU's kvotehandelssystem omfatter de største $\mathrm{CO}_{2}$-udledende virksomheder inden for energisektoren, $\mathrm{i}$ alt cirka 11.500 virksomheder i de 15 gamle EU-lande svarende til ca. 45 procent af EU-15's $\mathrm{CO}_{2}$-emissioner. EU's medlemsstater udsteder et antal kvoter (á et ton $\mathrm{CO}_{2}$ hver) for de kommende år, og hver af de omfattede virksomheder skal efterfølgende sikre sig en kvote for hvert ton $\mathrm{CO}_{2}$, som de udleder. Den samlede årlige udledning reguleres ved at regulere på antallet af udledningstilladelser. Der er altså lagt et loft over antallet af kvoter, og det vil gradvis blive sænket frem til 2012.
Det betyder, at at virksomheder, der har brug for ekstra kvoter ud over de gratis tildelte, skal ud og købe kvoter fra virksomheder, der sparer på energien, hvilket igen medfører, at det bliver dyrere at bruge fossile brændsler i produktionen.

EU har vedtaget at virksomhederne skal have de tildelte kvoter i henhold til det såkaldte bedstefarprincip - dvs. i forhold til hidtidig udledning. Det er også besluttet at virksomhederne skal have de tildelte kvoter gratis, selv om retten til at udlede $\mathrm{CO}_{2}$ gør dem værdifulde, fordi virksomhederne kan handle kvoterne med hinanden på tværs af sektorer og lande i EU. Den gratis allokering af kvoter til virksomhederne repræsenterer en gave til virksomhederne på mange milliarder euro.

Virksomhederne kan ud over at handle kvoter inden for EU købe såkaldte Joint Implementation-kvoter og CDM-kvoter fra klimaprojekter i lande uden for EU og bruge dem i EU's kvotehandelssystem.

Den praktiske fordeling af kvoter blandt virksomhederne sker ved, at hver medlemsstat udarbejder såkaldte nationale allokeringsplaner, som skal godkendes af Europa-Kommissionen. Flere medlemslande har af Europa-Kommissionen fået pålæg om at udstede færre $\mathrm{CO}_{2}$-kvoter, end de havde planlagt.

Systemet har fungeret på forsøgsbasis i siden 2005, men i den første fase er der blevet udstedt for mange kvoter. Derfor har virksomhederne 
ikke haft brug for at købe ret mange kvoter. Systemet skal derfor for alvor bestå sin prøve i den egentlige Kyoto-periode fra 2008-12, hvor EU har reduktionsforpligtelser. Hvis en virksomhed ikke afleverer kvoter svarende til deres $\mathrm{CO}_{2}$-udledning pålægges de bøder, der fra 2008 vil udgøre 100 euro per tons $\mathrm{CO}_{2}$ plus den manglende kvote.

Kvotehandelssystemet dækker som nævnt 45 procent af EU's $\mathrm{CO}_{2}$-udslip. Resten af landenes udledninger søges begrænset gennem en række andre former for regulering, både på EU-niveau og nationalt. Fx i form af normer og standarder for byggeri og højere afgifter på benzin og diesel til transport. Søfart og luftfart er ikke omfattet af Kyoto-aftalen.

\section{EU's ambitiøse mål}

Spørgsmålet er så, om EU-landene kan leve op til deres ambitiøse mål om en udslipsreduktion på 20 procent frem til 2020. I de femten år fra 1990 til 2005 har de 15 EU-lande kun reduceret deres udslip med 1,5 af de otte procent, som de har forpligtet sig til i Kyoto, fremgik det af en meddelelse fra Det europæiske Energiagentur i juni i år.

Det betyder næppe, at EU ikke opfylder Kyoto-målet i 2012, for reduktionen kan helt legalt opfyldes ved kvotehandel og energiinvesteringer i udviklingslande, men dette kan i realiteten anskues som en særlig form for udviklingsbistand, som det er meget lettere at skaffe penge til, end det er at reducere $\mathrm{CO}_{2}$-udslippet.

Det bemærkelsesværdige er imidlertid, at det reelt er ganske få lande, der har sikret den hidtidige reduktion på 1,5 procent.

Ser man bort fra Tyskland og Storbritannien, der tilsammen står for ca. 47 procent af EU-15's samlede emission og som begge har haft en stor nedgang i udslippet af drivhusgasser af årsager, der ikke har noget med Kyoto-aftalen at gøre - som omlægning eller afvikling af den stærkt energislugende energi i $\emptyset_{\text {st- }}$ tyskland og overgang til gasfyrede i stedet for kulfyrede kraftværker i Storbritannien - er emissionen fra de øvrige 13 EU-lande under ét steget med ca. 13 procent fra 1990 til 2005 ifølge en opgørelse fra Deutche Institut für Wirtschaftsforschung.

Til sammenligning havde USA med en procentvis langt større befolkningstilvækst end EU - en vækst på 16 procent, Australien og New Zealand begge 25 procent, Canada 31 procent, Japan knap otte procent og Norge 10 procent frem til 2005.

Danmark havde ifølge samme opgørelse et fald i udledningen på 7,7 procent fra 1990-2005. Det er mere end noget andet EU-land bortset fra Tyskland og Storbritannien. Reelt er der endda tale om en reduktion på 15-16 procent, hvis man sammenligner med Danmarks normaliserede udslip for 1990, hvad Miljøagenturet dog ikke gør. 
For gruppen af udviklingslande under et skete der imidlertid en dramatisk stigning i udslippet af drivhusgasser på cirka 75 procent fra 1990 til 2005.

Det indebærer, at den absolutte stigning i ulandenes udslip af drivhusgasser gennem de 15 år frem til 2005 er næsten 16 gange større end den nedskæring, som EU-landene forpligtede sig til i Kyoto.

Sammenligningen illustrerer den gigantiske opgave det er at reducere eller i det mindste begrænse det globale udslip af drivhusgasser, for stigningen tegner til at fortsætte. Ifølge en 2006 rapport fra Det internatio- nale Energiagentur vil den globale $\mathrm{CO}_{2^{-}}$emission med de nuværende politikker blive mere end fordoblet frem til 2050, og 70 procent af denne stigning vil komme i udviklingslandene. Denne vækst i $\mathrm{CO}_{2}$-emissionen afspejler, at fossile brændsler både i dag og i en lang årrække fremover ventes at stå for ca. 85 procent af verdens samlede energiforsyning.

Frede Vestergaard er фkonom og journalist ved Weekendavisen.

Artiklen er afleveret inden klimamødet $i$ Washington 27.-28. september. 